\title{
What is life like for our elderly? An empirical study of the quality of life of older people in Colombia ${ }^{1}$
}

\author{
Bilver Adrián Astorquiza Bustos and Óscar Armando Chingal
}

\begin{abstract}
Life expectancy has increased considerably over the last 50 years; and population pyramids have inverted as the number of older people has grown. This study analyses the quality of life enjoyed by older people in nine of Colombia's regions or departments, as rated in four categories: "Very good", "Good", "Fair" or "Poor". It estimates an ordered multinomial logistic model using 20,720 observations taken from the 2018 National Quality of Life Survey, which altogether represent 3,914,448 individuals. The results suggest that the average probability of having a quality of life rated good is $80.2 \%$, with variations between geographical areas and differences that are associated positively with being a woman, belonging to medium and high socioeconomic groups, not missing daily meals, having a home of one's own home, not being affiliated to the subsidized social security regime and not feeling insecure or poor, among other factors.
\end{abstract}

\section{Keywords}

Ageing person, quality of life, social welfare, measurement, evaluation, population aspects, surveys, statistical methodology, econometric models, Colombia

JEL classification

J14, I31, C35, 110

\section{Authors}

Bilver Adrián Astorquiza Bustos is a Professor and Research Fellow at the Faculty of Accounting, Economics and Administrative Sciences of the University of Manizales (Colombia). Email: bilvera@umanizales.edu.co.

Óscar Armando Chingal is a teacher at the Comfacauca University Corporation, at Santander de Quilichao (Colombia). Email: ochingal@unicomfacauca.edu.co. 


\section{Introduction}

Life expectancy has increased considerably over the last 50 years, as a result of technological progress, government policies to improve the population's living conditions and the early detection of diseases that compromise human health and for which effective treatments were not previously available. World Bank population indicators show that average life expectancy in Europe and Central Asia, North America, East Asia and the Pacific, the Middle East and North Africa, sub-Saharan Africa and Latin America and the Caribbean was 18.9 years shorter in the early 1960s than in 2017, which is evidence of increasing population longevity (see table 1).

Table 1

Life expectancy and population by geographical region

\begin{tabular}{|c|c|c|c|c|c|}
\hline \multirow{2}{*}{ Region } & \multicolumn{2}{|c|}{ Life expectancy } & \multicolumn{2}{|c|}{$\begin{array}{l}\text { Population } \\
\text { (millions) }\end{array}$} & \multirow{2}{*}{$\begin{array}{l}\text { Population growth } \\
\text { (percentages) }\end{array}$} \\
\hline & 1960 & 2017 & 1960 & 2017 & \\
\hline Colombia & 56.75 & 74.56 & 16.06 & 48.90 & 204.53 \\
\hline East Asia and the Pacific ${ }^{a}$ & 45.72 & 74.64 & 894.88 & 2068.16 & 131.11 \\
\hline Europe and Central Asia ${ }^{\mathrm{a}}$ & 63.39 & 73.18 & 275.15 & 415.71 & 51.09 \\
\hline Latin America and the Caribbean ${ }^{\mathrm{a}}$ & 55.64 & 75.57 & 204.21 & 603.25 & 195.40 \\
\hline North America & 69.89 & 78.94 & 198.62 & 361.75 & 82.13 \\
\hline Sub-Saharan Africa ${ }^{\mathrm{a}}$ & 40.38 & 60.80 & 227.19 & 1050.06 & 362.19 \\
\hline Middle East and North Africa ${ }^{\mathrm{a}}$ & 46.61 & 73.23 & 97.55 & 376.55 & 285.99 \\
\hline Average & 54.05 & 72.99 & & & \\
\hline
\end{tabular}

Source: Prepared by the authors, on the basis of data from the World Bank.

a Excluding high-income countries.

Colombia is no exception to this trend. The population projection report of the National Administrative Department of Statistics (DANE, 2017) states that the country had some 5,970,956 inhabitants aged 60 years or over (12.4\% of the population) in 2017; and, of these, an estimated $54.87 \%$ were women. World Bank figures for Colombia also support the hypothesis of an inversion of the population pyramid, since life expectancy increased from 56.75 years in 1960 to 74.56 in 2017. This demographic transition is also evidenced by an analysis of population growth between 2005 and 2017: while the number of young people aged 12 to 25 years increased by $6.1 \%$, the number of older persons (aged 60 or over) grew by 56.5\%. (DANE, 2017).

This population dynamic attracted research agendas in various fields towards studying ways to improve the living conditions of older people. The research is being led mainly by the clinical sciences, given the intrinsic relationship between an individual's quality of life and his/her health status, as demonstrated, for example, by the studies of Ehlke (1998), Bazo (1999), Rivera-Ledesma and Montero (2005) or Marín and others (2009). Although it has been possible to identify a number of factors associated with enhanced well-being among the older-age population (actions, behaviour or characteristics that are conducive to a better quality of life), the literature is still sparse, especially in the economic sciences.

As people today can expect to live longer than their forbears, there is an urgent need to examine the state of well-being of older persons, using quantitative methodologies of statistics and economics that are easy to transfer academically and could be replicated in other countries. This study therefore poses the following exploratory question: what were quality-of-life conditions like for older persons in Colombia in 2018? To answer this, an analysis is made of a set of factors that influence the likelihood that older people will have a quality of life rated very good, good, fair or poor. The ratings are obtained directly from the question on perceptions prepared by the National Administrative Statistics Department (DANE) of Colombia, which ranks the categories using the method of summary evaluations on a Likert 
scale. In the scientific domain, it has been found that when the number of categories is large, individuals tend to bias their response towards one category in particular. Accordingly the question designed by the Colombian institution has only four.

To answer the question referred to above, the following statement is tested as a research hypothesis: "In 2018 older people in Colombia are more likely to enjoy a quality of life rated good than one rated very good, fair or bad; nonetheless, this may be influenced by the region in which the person lives, which denotes the existence of specific conditions that reflect not only sociodemographic characteristics, but also geographical ones".

Quality of life is a multidimensional concept, since it is based on subjective and objective conditions that are present throughout the life cycle - such as income level, years of schooling, feelings of security, health status, personal satisfaction, family relations, social services and social participation (Giraldo and Arango, 2012, p. 161). Thus, to analyse the quality of life, a set of variables are introduced which, for simplicity, are condensed into four categories: (i) demographic characteristics, (ii) socioeconomic characteristics, (iii) employment relationships; and (iv) perceptions of the surroundings. This makes it possible to quantify the chances of having a very good, good, fair or bad quality of life, along with the associated characteristics.

This article is structured in five sections, including this introduction. Section II reviews the quality-of-life literature, specifically as regards the study group (older people). Section III then briefly discusses the demographic definition of older people, by chronological age, since this makes it possible to objectively define the population classified as older and also follows the criterion established by various international agencies. The next section describes the methodological approach: the control variables, their functional form, the justification for using the econometric method and the main sample statistics. Lastly, section $\mathrm{V}$ presents the results of the econometric inference, followed by conclusions, recommendations and the limitations of the study.

\section{Literature review}

Health is one of the factors associated with quality of life, since poor health generates bodily and mental problems that degrade an individual's well-being. Authors such as Ehlke (1998), Bazo (1999) and Rivera-Ledesma and Montero (2005) argue that a large proportion older people present health problems that tend to worsen with age, affecting their functional capacity and, hence, their quality of life. Along the same lines, Bazo (1999) specifies that the most prevalent diseases are chronic-degenerative ones, the severity of which depends on the lifestyle that individuals have led and on whether they attend periodic medical check-ups. Thus, despite being condensed in simplistic terms, it is clear that health affects an individual's quality of life, but how it does so is determined by his/her economic capacity.

The Fernández-Ballesteros study (1997) analyses the quality of life of 1,014 persons aged over 65 in Spain, in terms of variables such as health status, gender, functional skills, economic status, social relations, activity (social role) or access to social services, among others. In particular, it analyses whether there are quality-of-life differences that depend on the type of home in which the elderly person lives - in his/her own home, as a resident in a public institutions or else in a private institution. Based on this segmentation, the author finds that high socioeconomic level, male sex, middle and high income level and living in one's own home explain the presence of a better quality of life during old age, since such individuals report having better functional skills and greater social integration. However, there are no empirical data that support the hypothesis that the type of home, whether public or private, in which an elderly person lives, determines his/her quality of life exclusively. 
In another study, Chackiel (2000) analyses the implications of the increase in the number of older people in Latin America. A theoretical framework is used to show that not all people reach old age at the same time, since that stage of life is identified in terms of physical and cognitive abilities. Moreover, the author provides a conceptual overview of the inversion of the population pyramid (fewer births and more people surviving to an advanced age) due to the effect of the demographic transition associated with a country's development. The second part of the study focuses on the fiscal challenges of coordinating social investment in order to reduce the dependency rates that can affect older persons, since a scenario of fewer births and larger numbers of older people imposes a heavier burden on the State in the pension system, and reduces incentives for young people who are active in the labour market to contribute to private funds.

Bravo (2000) also analyses population ageing in Latin America, noting that the region has gone through a rapid demographic transition process and projecting low birth rates and much longer life expectancy in the years to come, which will affect pension systems and, therefore, the population's standard of living. Unlike the previous study (Chackiel, 2000), this author makes a more in-depth analysis of the fiscal sustainability of pension systems based on "the transition costs". He argues that, whereas countries such as Argentina and Cuba are in advanced stages of the demographic transition, Colombia is at an early stage. Nonetheless, he concludes that, in general, all economies face enormous huge in their pension systems, which justifies efforts to find mechanisms that will help alleviate the concomitant fiscal pressures.

In a diagnosis of the well-being of older persons in Latin America, the Economic Commission for Latin America and the Caribbean (ECLAC, 2004) states that older persons have difficulty accessing the pension system if they have engaged in informal economic activities during the productive stage of their life; and this situation leads to heavy social dependency on other persons, whether family members or others. In some cases, such third-party support is not available, leading to conditions of vulnerability that can result in poverty. The publication argues that this explains why the quality of life of older people is less than good: they have low coverage in the health system, precarious conditions of care and treatment of their illnesses, limited access to recreation and leisure, and occupational health problems. In contrast, affiliation to the social security system (as a sign of formal labour market activity) is associated with access to services that would otherwise be inaccessible, such as the health system.

The study by Arango and Ruiz (2006) analyses the trend of a number of socioeconomic indicators of Colombia's elderly population, by comparing the 2005 and 1993 population censuses. The authors suggest that there is still a clear social deficit in terms of elderly care, arguing that better indicators of access to the pension system and expanded coverage of the health system should lead to better living conditions. They also highlight this population group's susceptibility to poverty, which in principle is explained by low income at the pension stage; and they again emphasize the high rates of family dependency that tend to be created.

Ramírez-Vélez and others (2008) conducted a clinical study in the city of Santiago de Cali (Colombia) to analyse the socioeconomic and anthropometric variables associated with the emergence of chronic noncommunicable diseases among women aged 65 to 87 without physical or psychological difficulties and not hospitalized in any medical centre or residence. Their findings show that factors such as being overweight, suffering from hypertension and loss of functional capacity, which lead to a high prevalence of disabilities among this population, detract from their quality of life.

The effect of feeding habits and symptoms of depression on a person's quality of life has been addressed by Ávila-Funes, Garant and Aguilar-Navarro (2006), with an analysis based on 1,748 older people in Mexico. These authors applied a compendium of variables aligned on the categories of oral health, mental function and functionality, and used as a dependent variable the Yesavage geriatric depression scale, which ranges from 0 to 12 (scores above 6 indicate the presence of depressive symptoms). The results show that diet affects symptoms of depression; but dental problems, difficulty 
in handling money and high blood pressure are factors linked to the symptomatology of cognitive dysfunction and, therefore, also affect the quality of life of the elderly person. Thus, health conditions are again associated with quality of life, in this case highlighting the importance of feeding patterns.

Marín and others (2009) reiterate the multidimensional nature of quality of life, highlighting aspects associated with pathological, health, demographic, anthropometric, clinical and nutritional conditions, among others, which are clearly decisive for elderly well-being. The research analyses health promotion as a strategy to improve quality of life, using a sample of 700 older people in Argentina. The conclusion is that living alone in the home, having physical impairments and presenting depressive symptoms, cholesterol problems, overweight and nutritional risk are associated with fair or poor health; while a good quality of life is determined by the absence of pathological conditions that restrict mobility, such as obesity, heart disease or undernourishment, among others.

Estrada and others (2011) state that, although the concept of quality of life is multidimensional, each area of knowledge is approached from a different theoretical framework or methodological process: for economists the concept focuses on well-being, income and living standards and conditions. From a sample of 276 people over 65 years of age in the city of Medellín, the authors analyse the relationship between demographic characteristics, social support, nutritional status, symptoms of depression, anxiety risk and functional capacity, using the quality of life assessment scale for older people proposed by the World Health Organization (WHO). The profile of an older person with a lower score on the scale and, therefore, worse quality of life, can be characterized as follows: she is a woman, feels mistreated by family members and has diabetes, symptoms of depression and an increasingly limited functional capacity.

Melguizo, Acosta and Castellano (2012) were the first to use econometrics as a methodological strategy for measuring the quality of life of older people. The authors develop a logistic regression model and obtain results similar to those of this research, in terms of health-related quality of life. Firstly, they identify gender differences in quality of life: being a man is associated with better physical and emotional well-being, while women display better self-care. They also note that elderly pensioners, at any socioeconomic level other than low, who live in a free union and whose level of education is better than basic primary, display better physical and psychological well-being, self-care and occupational functioning.

As regards the interest of this research in finding a relationship between the labour market and quality of life, the study by Escarbajal and Martínez (2012) provides a relevant approach. These authors note that older people who are still productively employed score better in terms of quality of life than the unemployed; they argue that retirement is one of the most important changes an older person experiences: in most cases it leads to a loss of social status, reduces support networks and causes a drop in income, which leads to a redefinition of personal relationships with their surroundings.

Studies that analyse pensions and their impact on quality of life include that of Schatz and others (2012). These authors perform a quantitative and qualitative analysis of how pensions influence the well-being and health of men and women in South Africa. Using logistic regression as a contrasting method, they found that pensions had a particularly strong impact on the declared well-being of older women. However, qualitative data suggested that men initially used their pension to buy large household items, while women used it for daily household maintenance.

Lloyd-Sherlock and others (2012) make a comparative study of older people in South Africa and Brazil, considering the relationship between pension and well-being with data obtained from two surveys conducted in 2002 and 2008. In South Africa, older people were defined as those over 54 years of age, while in Brazil 60 was used as the cut-off age. The results of the 2002 survey support the claim that pensions could have a significant effect on the economic status of poorer households in countries such as Brazil and South Africa; while data from the 2008 survey suggest that the South African health system is much more effective in serving older people than its Brazilian counterpart, so pensions and the health system have a positive impact on the well-being of this population group. 
Another interesting finding on the effect of pensions on the quality of life of older people is provided by Kaushal (2014). The author analyses the pension system in India and its effect on people over 65, and notes that receiving pension is associated with an increase in expenditure on medical care. $\mathrm{He}$ also estimates that in 50 years' time $80 \%$ of the world's elderly will live in developing countries, since the increase in life expectancy is more recent in these countries.

Research on older people has continued in the clinical setting in the last few years. Rubio and others (2015) explain why the quality of life of older people ought to be studied; and they use the guidelines issued by health authorities in Cuba to establish standards for their quality of life. The authors argue that quality of life is determined by sociodemographic characteristics; so protocols are needed for a systematic evaluation to identify the key factors that lead to a better quality of life in domains such as mental health, public and private services, social protection, the economy and education, among others. The authors argue that improving the quality of life is more important than increasing life expectancy.

Varela and Gallego (2015) make a qualitative assessment of the perception of quality of life among a group of older people located in Envigado (Colombia). The authors selected a sample of people with different income levels and interviewed them to identify the subjective and objective conditions that could affect their quality of life. Based on analytical categories, various elements were identified which showed that retirement income was a decisive factor in enabling older persons to live independently from their families; and that leisure activities, State support and access to a good health system were essential to ensure a good quality of life. On the other hand, it was noted that women were at a disadvantage compared to men, since they were less likely to have worked in the formal sector having been engaged in household activities, so they did not have access to a pension.

Alba and others (2017) note that roughly $1.2 \%$ of older persons in Colombia live in old-people's homes, and classify their quality of life on the basis of physical, psychological, relational and environmental dimensions. To identify these factors, the authors used the WHO instrument to measure quality of life, and compared its indicators on the basis of a qualitative and descriptive study with people aged 60 or older. It was found that the municipalities of Cajicá and Tenjo offered a better quality of life, despite low scores in the psychological and relational dimensions. The most revealing finding was that there was no correlation between age and quality of life, nor significant differences between the sexes within the sample, which concurs with some of the results found in this research.

A cross-sectional study by Pons and others (2018), to analyse the quality of life of older people living in a geriatric hospital in the town of Manzanillo (Cuba), found that individuals with a low level of schooling tended to perceive their quality of life as bad as they grew older. The perception of health was also an important determinant of quality of life for the individuals in the sample. A comparison of the results of previous studies with more recent ones shows differences in terms of the relationship between the age of older people and how they perceive their quality of life, while the relationship between this and the level of schooling was constant.

This literature review has reported research aimed at studying the factors that influence the quality of life of older people; but this type of research is still sparse. Its conclusions reveal the importance of incorporating components ranging from the physical conditions of the individual and his/her health status, to socioeconomic and demographic variables as a way of defining the concept of quality of life more precisely. However, most of the studies investigate clinical conditions and characteristics that can only be identified in health-oriented surveys. This is the main shortcoming of this research: there is no information on the symptoms or diseases displayed by this population group in Colombia, since the data in question were not available in the information sources used; and the National Demographic and Health Survey (ENDS) does not contain a module addressing these requirements, nor does it include a module for the representativeness of the national population. 
This research therefore identifies the quality of life of older people in the nine major regions of Colombia through probabilistic estimation. It recognizes the multidimensional nature of the concept of quality of life and includes characteristics associated with the four key categories of analysis presented above. This is one of the contributions of this research from the standpoint of the economic sciences, since there are few studies that enable significant inferences to be made for an entire population group. Similarly, the profile of the older person with a good or bad quality of life is identified, and an assessment is made of whether quality of life changes according to the region in which the person in question lives.

\section{Demographic definition of older persons}

As individuals enter a stage of the life cycle in which age directly affects their social and motor functioning and involves the loss of social and family roles, their participation in different environments, such as work, declines. In this sense, the chronological connotation of age becomes the most appropriate conceptual framework for defining the population group targeted in this research. This conceptual approach to age makes it possible to overcome the lack of theoretical consensus that has developed around the term "old age" (older persons); although the concept of old age forms part of life cycle theory, which also uses discriminatory criteria in its definition based on approaches such as physiological age and social age. Abstracting a biological definition based on the number of years that a person has lived presupposes a series of norms that define an individual's responsibilities and privileges (Araníbar, 2001) and, therefore, make it possible to identify the population group objectively.

An example of this is Colombia's Law 1.276 of 2009, which defines an older person as an individual aged 60 years or older, or someone between 55 and 60 years of age with specific physiological and psychological conditions. This law argues that grouping social agents by age makes it possible to determine the social appearance of old age, which in turn reflects social conventions such as that a person ages as his/her age increases (Araníbar, 2001, p. 12).

While there are alternative approaches to understanding the concept of older person, such as the social approach and the theory of modernization, to name just two, adopting them would make the definition depend on a range of socially accepted behaviours and patterns, including physical, demographic, cultural and socioeconomic characteristics. This would require an extensive conceptual framework that goes well beyond the objectives and scope of this research. Any definition other than the age of the individual would mean creating a metric that incorporates these social factors, which are often subjective.

Accordingly - and as a second shortcoming of the research - the data source used only makes it possible to objectively define the condition of older person by the age that the individual declares at the time of completing the form in the National Quality of Life Survey, and not by the way in which society perceives the individual, or by his or her health status. Establishing the age at which the biological, psychological and social characteristics of ageing usually appear is undoubtedly a complex process, since it is clearly not the same for every individual. Moreover, the definition of collective criteria for doing so would be biased by the objectives being pursued by the researchers. Nonetheless, it would likely be more useful, since it would incorporate components that could not be captured by age (a person of 60 in good health is not the same as someone of 60 who is mobility-impaired due to illness).

Various authors have also used criteria other than age to define older people. These include Pugliese (2010), who discusses demographic criteria. Although the theoretical discussion focuses on cognitive and physical capacities to define older people, it also notes that the international policy criterion established by the United Nations, ECLAC and WHO is based on age: 60 years of age is considered the appropriate time in the life cycle to start to refer to an individual as an "older person". 
Nonetheless, the author notes that, as age increases, the implications for health, care and dependency also increase; so special attention should be paid to people over 75 and 85 years of age, who may well represent the third and fourth ages, respectively. The author makes this reflection in view of the fact that life expectancy has already surpassed 85 years in several parts of the world, and the characteristics of the individual display greater deterioration.

\section{Methodological considerations}

The 2018 National Quality of Life Survey was considered the appropriate data source for this research, since its forms contain multiple components that reveal the socioeconomic, demographic and geographical conditions that, in conjunction with the age variable, identify 20,720 people aged 60 years or older, representing about 3,914,448 individuals from nine regions of the country. Moreover, as it is a household survey conducted by DANE, its sample design is probabilistic, stratified, multi-stage, conglomerate and representative of the national territory (DANE, 2016, p. 6).

The dependent variable adopts the functional form proposed by DANE in the entry "Currently, living conditions in your home are...", formulated to investigate how people perceive their quality of life. This involves a subjective response, because a person's perception is determined by the conditions in which he/she lives. The choice of this formula is justified by the ad hoc multidimensionality of the quality-of-life concept, whereby its measurement must incorporate a series of components that depend on each individual, and any quantitative proposal to construct it would incorporate a researcher's bias. In statistical terms, this variable adopts a four-category Likert scale, which reduces the likelihood of respondents biasing their response towards a particular category. Its interpretation must also be a specific observation on which an econometric analysis is performed and which, conditioned by control variables, identifies both the probability that an individual enjoys a good quality of life and the profile associated with this condition. Thus, the dependent variable is ranked from highest to lowest with four possible replies: "Very good", "Good", "Fair" or "Bad", for which DANE does not provide any definition or interpretation.

The explanatory or control variables are arranged in four central groups. The first is demographic, which encompasses three variables: the sex of the individual as a phenotypic distinction, taking the value one if male and zero if female; age, in order to analyse whether quality of life deteriorates with age; and membership of an ethnic-racial minority (a variable that includes individuals who identify themselves as Afro-Colombians, Raizales, Palanqueros, Mulatos, Roma or Indigenous), taking the value one if the individual belongs to one of these groups and zero otherwise.

The second component is socioeconomic and consists of 11 variables: socioeconomic level, the highest level of education attained, marital status, whether or not the individual owns his or her home, the number of people living in the household, whether daily meals are limited by lack of income, whether or not the home has access to public water supply, whether it is connected to the gas network, and whether it uses firewood, charcoal or waste material for cooking. Total household income is also studied in order to determine whether there is a close link between monetary resources and quality of life, a relationship revealed in some of the research documented thus far; and, lastly, whether the individual receives income from the Colombia Mayor programme, since that programme's monetary transfers aim to improve the living conditions of older people living in poverty by increasing their income.

The third component, employment relationships, analyses older people's labour market participation, paying special attention to whether or not they receive a pension and the social security system to which they are affiliated: contributory, special or subsidized. This makes it possible to establish whether the loss of social roles implicit in labour market participation over the years is associated with a deterioration in the quality of life. 
The final component is perceptions: it groups the variables that make it possible to analyse (without specifying degree) how the individual's quality of life is affected by conditions that are specific to his/her environment and change how he/she perceives reality. The following variables are studied: feelings of security, poverty status, health status and quality of the social security system to which he/ she is affiliated. Lastly, the region variable is introduced into this analysis to capture one-off fixed effects that would increase the chances that older people enjoy a better quality of life just because they live in a specific place. This evaluation seeks to clarify whether there are differences between the following regions or departments: Capital District of Bogotá, the Central, Atlantic, Eastern and Pacific regions, and the departments of Antioquia and Valle del Cauca, the island department of San Andrés and the department of Amazonas in the Orinoco region. This is based on the hypothesis that the national capital has a larger number of resources and services, better centres of attention and other specific features that could imply better care for this population group. ${ }^{2}$ The estimated econometric specification is as follows:

$$
\begin{gathered}
\text { CVAM }_{i}=\sum_{j=1}^{3} \beta_{j} X_{j_{\text {Demographic }_{i}}}+\sum_{j=1}^{11} \beta_{j} X_{j_{\text {Socioeconomic }_{i}}}+\sum_{j=1}^{2} \beta_{j} X_{j_{\text {Labour_participation }_{i}}} \\
+\sum_{j=1}^{4} \beta_{j} X_{j_{\text {Perception_environment }_{i}}}+\text { Dummy_Region }_{i}+\varepsilon_{i} \text { with } i=1,2,3,4
\end{gathered}
$$

The equation represents an ordered multinomial logistic model, where the subscript i refers to one of the four categories of the dependent variable CVAM (calidad de vida del adulto mayor - quality of life of the older adult). The four key categories of the study are accompanied by the coefficients $\beta_{j}$ and the parameters $X_{j}$ representing the independent variables, thus facilitating understanding of the number of variables introduced into the model in accordance with the established components.

Before conducting the estimation process, the suitability of implementing the first modelling alternative (ordered logit model) was validated through the Akaike and Bayesian information criteria (AIC and $\mathrm{BIC}$, respectively); it was found that the technique proposed was correct, since in both cases the information criterion was of lower magnitude in the logit. This decision criterion is presented in annex table A1.3; while table A1.4, based on the variance inflation factor, shows that there is no correlation between the independent variables that could cause multicollinearity and large variances in the estimates. This invalidates the hypothesis of statistical significance, since the average value of the statistic was less than 10 and, according to Mansfield and Helms (1982), the smaller the model the less likely it will suffer from problems related to this condition.

\section{Econometric inference and results}

The estimation of this econometric model shows that the probability of having a quality of life rated good is $80.2 \%$, whereas the chance of a quality of life rated fair is $14.85 \%$. This finding confirms the research hypothesis as formulated, since in 2018 older people in Colombia had a good quality of life; and the difference between this and the next category in probabilistic terms was over 65.35 percentage points. This suggests that a large proportion of older people in Colombia perceive their living conditions as good and express their well-being. However, a significant number of older people rate their quality of life as fair, which makes it possible to compare the characteristics that determine the probability of having a good or fair quality of life. For this purpose, the coefficients and signs found in the four key components reported in the estimate in table 2 are considered in detail: the marginal effects $(d y / d x)$ of the ordered multinomial logistic regression (logit) model.

2 Tables A1.1 and A1.2 in the Annex present the functional form of the variables and their main statistics, respectively. 
Table 2

Colombia: ordered multinomial logistic regression model $(d y / d x)$ of the key components in the study of the quality of life of older people

\begin{tabular}{|c|c|c|c|c|c|}
\hline & Characteristics by component & Bad & Fair & Good & Very good \\
\hline \multirow[t]{4}{*}{ Demographic } & Sex [1=Male] & $\begin{array}{l}0.0007^{\star \star \star} \\
(0.0002)\end{array}$ & $\begin{array}{l}0.0189^{\star \star \star} \\
(0.0051)\end{array}$ & $\begin{array}{l}-0.0129^{\star \star \star} \\
(0.0034)\end{array}$ & $\begin{array}{l}-0.0066^{\star \star \star} \\
(0.0018)\end{array}$ \\
\hline & Ethnic minorities [1=If a member] & $\begin{array}{l}-0.0001 \\
(0.0002)\end{array}$ & $\begin{array}{l}-0.0023 \\
(0.0069)\end{array}$ & $\begin{array}{c}0.0016 \\
(0.0047)\end{array}$ & $\begin{array}{l}0.0008 \\
(0.0024)\end{array}$ \\
\hline & Between 75 and 90 years of age & $\begin{array}{l}-0.0002 \\
(0.0002)\end{array}$ & $\begin{array}{l}-0.0049 \\
(0.0048)\end{array}$ & $\begin{array}{c}0.0033 \\
(0.0033)\end{array}$ & $\begin{array}{l}0.0017 \\
(0.0017)\end{array}$ \\
\hline & Over 90 years of age & $\begin{array}{l}0.0037^{\star \star \star} \\
(0.0012)\end{array}$ & $\begin{array}{l}0.0923^{\star \star \star} \\
(0.0254)\end{array}$ & $\begin{array}{l}-0.0757^{\star \star \star} \\
(0.0230)\end{array}$ & $\begin{array}{l}-0.0203^{\star \star \star} \\
(0.0036)\end{array}$ \\
\hline \multirow[t]{17}{*}{ Socioeconomic } & Middle socioeconomic level & $\begin{array}{l}-0.0015^{\star \star \star} \\
(0.0002)\end{array}$ & $\begin{array}{l}-0.0440^{\star \star \star} \\
(0.0053)\end{array}$ & $\begin{array}{l}0.0285^{\star \star \star} \\
(0.0033)\end{array}$ & $\begin{array}{l}0.0170^{\star \star *} \\
(0.0023)\end{array}$ \\
\hline & High socioeconomic level & $\begin{array}{l}-0.0028^{\star * *} \\
(0.0002)\end{array}$ & $\begin{array}{l}-0.0862^{\star \star *} \\
(0.0054)\end{array}$ & $\begin{array}{l}0.0334^{* * *} \\
(0.0020)\end{array}$ & $\begin{array}{l}0.0557^{* * *} \\
(0.0064)\end{array}$ \\
\hline & $\begin{array}{l}\text { Misses one of the three main meals owing } \\
\text { to lack of money }\end{array}$ & $\begin{array}{l}0.0064^{\star \star \star} \\
(0.0008)\end{array}$ & $\begin{array}{l}0.1485^{\star \star \star} \\
(0.0152)\end{array}$ & $\begin{array}{l}-0.1273^{\star \star \star} \\
(0.0144)\end{array}$ & $\begin{array}{l}-0.0277^{\star \star \star} \\
(0.0017)\end{array}$ \\
\hline & Access to public water supply & $\begin{array}{l}-0.0010^{\star \star \star} \\
(0.0002)\end{array}$ & $\begin{array}{l}-0.0295^{\star \star \star} \\
(0.0060)\end{array}$ & $\begin{array}{l}0.0191^{* * *} \\
(0.0036)\end{array}$ & $\begin{array}{l}0.0115^{\star \star \star} \\
(0.0026)\end{array}$ \\
\hline & Access to natural gas & $\begin{array}{l}-0.0007^{\star \star \star} \\
(0.0002)\end{array}$ & $\begin{array}{l}-0.0190^{\star \star \star} \\
(0.0061)\end{array}$ & $\begin{array}{l}0.0134^{\star \star \star} \\
(0.0044)\end{array}$ & $\begin{array}{l}0.0062^{* \star \star} \\
(0.0019)\end{array}$ \\
\hline & $\begin{array}{l}\text { Uses firewood, charcoal, or waste material } \\
\text { as a fuel for cooking }\end{array}$ & $\begin{array}{l}0.0011^{\star \star \star} \\
(0.0003)\end{array}$ & $\begin{array}{l}0.0311^{\star \star \star} \\
(0.0088)\end{array}$ & $\begin{array}{l}-0.0230^{\star \star \star} \\
(0.0069)\end{array}$ & $\begin{array}{l}-0.0093^{\star \star \star} \\
(0.0023)\end{array}$ \\
\hline & Lives alone & $\begin{array}{l}0.0011^{\star * \star} \\
(0.0002)\end{array}$ & $\begin{array}{l}0.0310^{\star \star \star} \\
(0.0051)\end{array}$ & $\begin{array}{l}-0.0201^{\star \star \star} \\
(0.0031)\end{array}$ & $\begin{array}{l}-0.0120^{\star \star \star} \\
(0.0022)\end{array}$ \\
\hline & Household income & $\begin{array}{l}-0.0012^{\star * *} \\
(0.0001)\end{array}$ & $\begin{array}{l}-0.0334^{* \star *} \\
(0.0025)\end{array}$ & $\begin{array}{l}0.0231^{* \star *} \\
(0.0018)\end{array}$ & $\begin{array}{l}0.0115^{\star \star *} \\
(0.0009)\end{array}$ \\
\hline & Basic primary or preschool & $\begin{array}{l}-0.0001 \\
(0.0002)\end{array}$ & $\begin{array}{l}-0.0023 \\
(0.0063)\end{array}$ & $\begin{array}{c}0.0016 \\
(0.0043)\end{array}$ & $\begin{array}{l}0.0008 \\
(0.0022)\end{array}$ \\
\hline & Basic secondary or upper secondary & $\begin{array}{l}0.0002 \\
(0.0003)\end{array}$ & $\begin{array}{c}0.0054 \\
(0.0080)\end{array}$ & $\begin{array}{l}-0.0037 \\
(0.0056)\end{array}$ & $\begin{array}{l}-0.0018 \\
(0.0027)\end{array}$ \\
\hline & $\begin{array}{l}\text { Technician/technologist with } \\
\text { or without diploma }\end{array}$ & $\begin{array}{l}-0.0014^{\star \star \star} \\
(0.0003)\end{array}$ & $\begin{array}{l}-0.0418^{\star \star \star} \\
(0.0092)\end{array}$ & $\begin{array}{l}0.0242^{\star \star \star} \\
(0.0041)\end{array}$ & $\begin{array}{l}0.0190^{* \star *} \\
(0.0055)\end{array}$ \\
\hline & $\begin{array}{l}\text { University/postgraduate with } \\
\text { or without diploma }\end{array}$ & $\begin{array}{l}-0.0015^{\star * *} \\
(0.0003)\end{array}$ & $\begin{array}{l}-0.0446^{\star \star \star} \\
(0.0081)\end{array}$ & $\begin{array}{l}0.0268^{* * \star} \\
(0.0041)\end{array}$ & $\begin{array}{l}0.0193^{* * *} \\
(0.0044)\end{array}$ \\
\hline & Free union & $\begin{array}{l}0.0007^{\star * *} \\
(0.0003)\end{array}$ & $\begin{array}{l}0.0203^{\star \star \star} \\
(0.0070)\end{array}$ & $\begin{array}{l}-0.0146^{\star * \star} \\
(0.0052)\end{array}$ & $\begin{array}{l}-0.0064^{\star \star *} \\
(0.0020)\end{array}$ \\
\hline & Widow & $\begin{array}{l}0.0011^{\star * *} \\
(0.0003)\end{array}$ & $\begin{array}{l}0.0297^{\star \star \star} \\
(0.0073)\end{array}$ & $\begin{array}{l}-0.0214^{* * *} \\
(0.0055)\end{array}$ & $\begin{array}{l}-0.0094^{* * *} \\
(0.0021)\end{array}$ \\
\hline & Separated or single & $\begin{array}{l}0.0021^{\star \star *} \\
(0.0003)\end{array}$ & $\begin{array}{l}0.0555^{\star \star *} \\
(0.0075)\end{array}$ & $\begin{array}{l}-0.0412^{\star \star \star} \\
(0.0059)\end{array}$ & $\begin{array}{l}-0.0164^{* \star \star} \\
(0.0019)\end{array}$ \\
\hline & Own home [1= Yes] & $\begin{array}{l}-0.0014^{\star * \star} \\
(0.0002)\end{array}$ & $\begin{array}{l}-0.0385^{\star \star \star} \\
(0.0050)\end{array}$ & $\begin{array}{l}0.0279^{* * \star} \\
(0.0038)\end{array}$ & $\begin{array}{l}0.0120^{\star \star \star} \\
(0.0014)\end{array}$ \\
\hline & $\begin{array}{l}\text { Colombia Mayor programme } \\
{[1=\text { receives this subsidy] }}\end{array}$ & $\begin{array}{l}0.0004^{*} \\
(0.0002)\end{array}$ & $\begin{array}{r}0.0099^{\star} \\
(0.0059)\end{array}$ & $\begin{array}{l}-0.0070^{*} \\
(0.0042)\end{array}$ & $\begin{array}{l}-0.0033^{*} \\
(0.0019)\end{array}$ \\
\hline \multirow[t]{3}{*}{$\begin{array}{l}\text { Employment } \\
\text { status }\end{array}$} & Receives a pension $[1=$ Yes $]$ & $\begin{array}{l}0.0003 \\
(0.0002)\end{array}$ & $\begin{array}{l}0.0080 \\
(0.0054)\end{array}$ & $\begin{array}{l}-0.0055 \\
(0.0037)\end{array}$ & $\begin{array}{l}-0.0028 \\
(0.0020)\end{array}$ \\
\hline & Special regime & $\begin{array}{l}-0.0008^{\star *} \\
(0.0003)\end{array}$ & $\begin{array}{l}-0.0221^{* *} \\
(0.0088)\end{array}$ & $\begin{array}{l}0.0141^{* \star *} \\
(0.0051)\end{array}$ & $\begin{array}{l}0.0088^{\star *} \\
(0.0040)\end{array}$ \\
\hline & Subsidized social security regime & $\begin{array}{l}0.0024^{\star \star \star} \\
(0.0003)\end{array}$ & $\begin{array}{l}0.0659^{\star \star \star} \\
(0.0067)\end{array}$ & $\begin{array}{l}-0.0465^{\star \star \star} \\
(0.0049)\end{array}$ & $\begin{array}{l}-0.0218^{\star \star \star} \\
(0.0022)\end{array}$ \\
\hline \multirow[t]{8}{*}{ Perceptions } & Feels secure in place of residence & $\begin{array}{l}-0.0058^{\star * \star} \\
(0.0005)\end{array}$ & $\begin{array}{l}-0.1420^{\star \star *} \\
(0.0075)\end{array}$ & $\begin{array}{l}0.1159^{\star \star \star} \\
(0.0068)\end{array}$ & $\begin{array}{l}0.0319^{* \star \star} \\
(0.0013)\end{array}$ \\
\hline & Self-defines as poor & $\begin{array}{l}0.0058^{\star * \star} \\
(0.0004)\end{array}$ & $\begin{array}{l}0.1498^{\star \star \star} \\
(0.0060)\end{array}$ & $\begin{array}{l}-0.1133^{\star * \star} \\
(0.0051)\end{array}$ & $\begin{array}{l}-0.0424^{\star \star \star} \\
(0.0017)\end{array}$ \\
\hline & Quality of the health service considered bad & $\begin{array}{l}-0.0016^{\star \star \star} \\
(0.0003)\end{array}$ & $\begin{array}{l}-0.0479^{\star \star \star} \\
(0.0092)\end{array}$ & $\begin{array}{l}0.0289^{\star \star \star} \\
(0.0046)\end{array}$ & $\begin{array}{l}0.0207^{\star * \star} \\
(0.0050)\end{array}$ \\
\hline & Quality of the health service considered good & $\begin{array}{l}-0.0029^{* * *} \\
(0.0005)\end{array}$ & $\begin{array}{l}-0.0783^{\star * \star} \\
(0.0122)\end{array}$ & $\begin{array}{l}0.0585^{\star \star \star} \\
(0.0097)\end{array}$ & $\begin{array}{l}0.0228^{* * *} \\
(0.0031)\end{array}$ \\
\hline & $\begin{array}{l}\text { Quality of the health service considered } \\
\text { very good }\end{array}$ & $\begin{array}{l}-0.0039^{\star * *} \\
(0.0003)\end{array}$ & $\begin{array}{l}-0.1192^{\star \star \star} \\
(0.0055)\end{array}$ & $\begin{array}{l}0.0174^{\star * \star} \\
(0.0067)\end{array}$ & $\begin{array}{l}0.1056^{\star * *} \\
(0.0115)\end{array}$ \\
\hline & Health status bad & $\begin{array}{l}-0.0024^{\star * *} \\
(0.0004)\end{array}$ & $\begin{array}{l}-0.0674^{\star \star *} \\
(0.0102)\end{array}$ & $\begin{array}{l}0.0434^{* * *} \\
(0.0061)\end{array}$ & $\begin{array}{l}0.0264^{* * *} \\
(0.0046)\end{array}$ \\
\hline & Health status fair & $\begin{array}{l}-0.0061^{\star * \star} \\
(0.0006)\end{array}$ & $\begin{array}{l}-0.1607^{\star \star *} \\
(0.0127)\end{array}$ & $\begin{array}{l}0.1144^{\star \star *} \\
(0.0094)\end{array}$ & $\begin{array}{l}0.0524^{* \star *} \\
(0.0042)\end{array}$ \\
\hline & Health status good & $\begin{array}{l}-0.0045^{* * *} \\
(0.0003)\end{array}$ & $\begin{array}{l}-0.1431^{\star * *} \\
(0.0039)\end{array}$ & $\begin{array}{l}0.0911^{* * *} \\
(0.0191)\end{array}$ & $\begin{array}{l}0.2386^{\star * *} \\
(0.0220)\end{array}$ \\
\hline
\end{tabular}


Table 2 (concluded)

\begin{tabular}{|c|c|c|c|c|c|}
\hline & Characteristics by component & $\mathrm{Bad}$ & Fair & Good & Very good \\
\hline \multirow[t]{11}{*}{$\begin{array}{l}\text { Region or } \\
\text { department }\end{array}$} & Central & $\begin{array}{l}-0.0007^{\star * *} \\
(0.0002)\end{array}$ & $\begin{array}{l}-0.0195^{\star \star \star} \\
(0.0070)\end{array}$ & 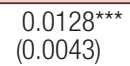 & $\begin{array}{l}0.0074^{* *} \\
(0.0030)\end{array}$ \\
\hline & Atlantic & $\begin{array}{c}0.0005^{*} \\
(0.0003)\end{array}$ & $\begin{array}{c}0.0129^{*} \\
(0.0077)\end{array}$ & $\begin{array}{l}-0.0092^{*} \\
(0.0056)\end{array}$ & $\begin{array}{l}-0.0042^{*} \\
(0.0024)\end{array}$ \\
\hline & Eastern & $\begin{array}{c}0.0000 \\
(0.0003)\end{array}$ & $\begin{array}{c}0.0005 \\
(0.0071)\end{array}$ & $\begin{array}{l}-0.0004 \\
(0.0049)\end{array}$ & $\begin{array}{c}-0.0002 \\
(0.0024)\end{array}$ \\
\hline & Pacific & $\begin{array}{l}0.0010^{\star *} \\
(0.0004)\end{array}$ & $\begin{array}{l}0.0281^{* *} \\
(0.0115)\end{array}$ & $\begin{array}{l}-0.0208^{* *} \\
(0.0089)\end{array}$ & $\begin{array}{l}-0.0084^{\star * \star} \\
(0.0030)\end{array}$ \\
\hline & Antioquia & $\begin{array}{c}0.0003 \\
(0.0003)\end{array}$ & $\begin{array}{c}0.0092 \\
(0.0077)\end{array}$ & $\begin{array}{l}-0.0065 \\
(0.0055)\end{array}$ & $\begin{array}{l}-0.0030 \\
(0.0025)\end{array}$ \\
\hline & Valle del Cauca & $\begin{array}{l}-0.0005^{\star *} \\
(0.0003)\end{array}$ & $\begin{array}{l}-0.0151^{\star *} \\
(0.0075)\end{array}$ & $\begin{array}{l}0.0100^{\star *} \\
(0.0048)\end{array}$ & $\begin{array}{c}0.0056^{*} \\
(0.0030)\end{array}$ \\
\hline & Island-San Andrés & $\begin{array}{l}-0.0000 \\
(0.0021)\end{array}$ & $\begin{array}{l}-0.0003 \\
(0.0580)\end{array}$ & $\begin{array}{c}0.0002 \\
(0.0400)\end{array}$ & $\begin{array}{c}0.0001 \\
(0.0201)\end{array}$ \\
\hline & Orinoco-Amazonas & $\begin{array}{l}-0.0006 \\
(0.0005)\end{array}$ & $\begin{array}{l}-0.0177 \\
(0.0145)\end{array}$ & $\begin{array}{c}0.0115 \\
(0.0087)\end{array}$ & $\begin{array}{c}0.0069 \\
(0.0063)\end{array}$ \\
\hline & Probability of occurrence & $0.45 \%$ & $14.85 \%$ & $80.18 \%$ & $4.52 \%$ \\
\hline & Pseudo $\mathrm{R}^{2}$ & \multicolumn{4}{|c|}{0.225} \\
\hline & No. of observations & \multicolumn{4}{|c|}{20720} \\
\hline
\end{tabular}

Source: Prepared by the authors, on the basis of data from the Quality of Life National Survey (ENCV) 2018.

Note: The asterisks indicate that the variables are significant at the $10 \%\left({ }^{*}\right), 5 \%\left(^{(\star}\right)$ and $1 \%\left({ }^{\star \star *}\right)$ levels.

The demographic component produces three important results: the first suggests the existence of gender-based differences in the quality of life. The coefficient is significant in all four categories of this component; and, although the magnitude is relatively low, the analysis concludes that older men are less likely to have a good quality of life. This contradicts the findings of Fernández-Ballesteros (1997) and Estrada and others (2011), which both claim that men have a better quality of life; while Vega (2009, p. 98) reinforces this argument by stating that, as men withdraw from the labour market at a later age, they postpone household responsibilities that are usually assumed by women, and this enhances their self-care and positively affects their quality of life. Nonetheless, this author also notes that a homogeneous structure cannot be assumed when studying old age; on the contrary, it must be heterogeneous, because of the biological factors that cause bodily change and the emergence of diseases.

On the other hand, when exploring individual characteristics such as ethnic-racial status, the results differ from those associated with the variable "sex". Although the coefficients are not statistically significant, they suggest that quality of life does not differ between ethnic minorities during old age, although the estimated coefficients for the good and very good categories are positive. This reiterates the need for studies targeting this population group, because its percentage in the "Fair" and "Bad" categories falls less steeply than in the case of the non-minority population when evaluating the quality of life in statistical terms (see figure 1).

The third result of this component uses the assumption that the older person's age adversely affects quality of life at some point. This variable considers persons aged between 60 and 74 years, those between 75 and 90 , and those over 90 years old. The results of the estimation show that a person over 90 years of age is 7.7 percentage points less likely to have a good quality of life than someone aged between 60 and 74; while the result for those between 75 and 90, while not significant, is positive, suggesting that the quality of life in this stage of life is better than later. This would seem to indicate that the older you are, the poorer your quality of life. Cuervas (2004) and Vega (2009) argue that people aged between 75 and 90 tend to receive greater support from family members or government entities, who mainly look after their emotional and physical health; and that there is a degree of social conformism that has accepted many of the changes that old age brings with it (such as the feeling of loneliness produced by a distancing from one's children), which would explain the result displayed by this group. The second result concurs with the literature referring to the fourth age, which argues that feelings such as loneliness, loss of mobility and decreased social participation become inevitable with age, to the detriment of mental health. 
Figure 1

Colombia: quality of life of older people by ethno-racial status, 2018

(Percentages)

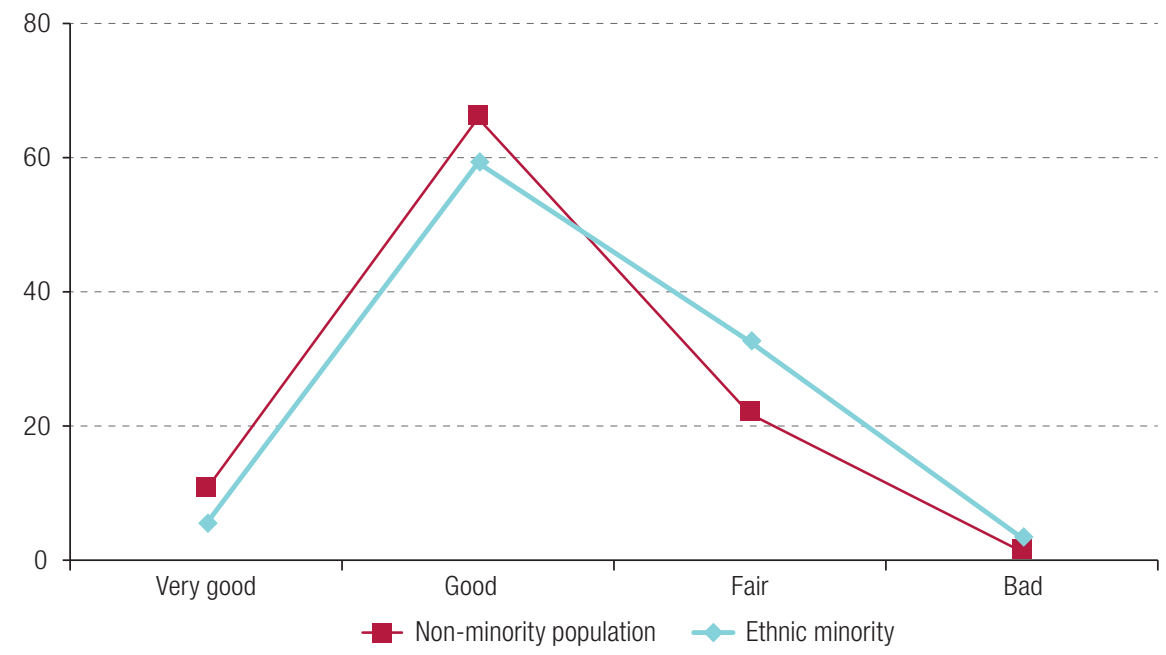

Source: Prepared by the authors, on the basis of data from the Quality of Life National Survey (ENCV) 2018.

The socioeconomic component considers the relationship between quality of life and the social status of individuals resulting from lifelong habits and which affects their well-being. Belonging to the middle and upper socioeconomic level reduces the likelihood of having only a fair quality of life by 4.40 and 8.86 percentage points, respectively, compared to being in the lower socioeconomic bracket. When the econometric analysis is complemented with the statistical analysis (see figure 2), it can be seen that none of the older people in the upper bracket perceives that living conditions in their household are bad; on the contrary, $96.81 \%$ state that their conditions are either very good or good, and only $3.19 \%$ describe their quality of life as fair. Conversely, $32.73 \%$ of older people in the lower bracket rate their living conditions as either fair or poor. Thus, a good quality of life seems to depend on socioeconomic status, which is a product of the capacity of individuals to accumulate wealth from an early age.

Figure 2

Colombia: quality of life of older people by socioeconomic status, 2018

(Percentages)

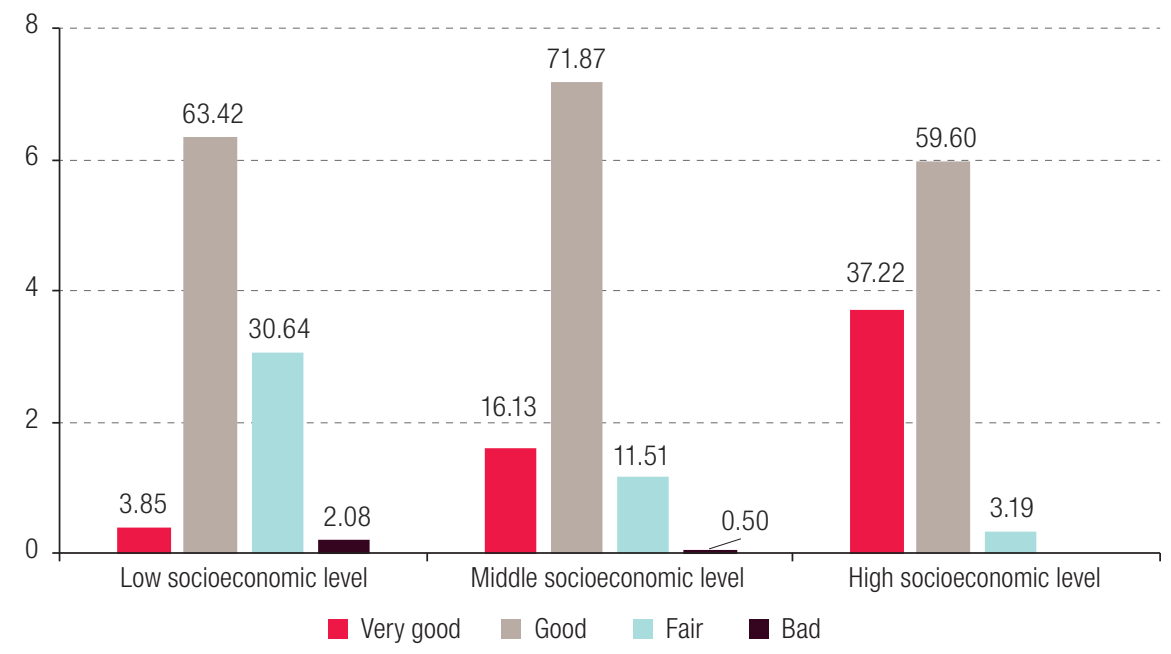

Source: Prepared by the authors, on the basis of data from the Quality of Life National Survey (ENCV) 2018. 
Household income, the possession of certain goods and certain feeding habits are all factors that can have a positive effect on the quality of life. As household income rises, the probability of having only a fair quality of life falls by 3.34 percentage points. In fact the effect of income is significant at $1 \%$ in all four categories of the study. The possession of certain goods in the household also reflects an individual's purchasing power; and analysis shows, for example, that the probability of having a very good quality of life is reduced by 0.93 percentage points for older people who use rudimentary materials such as firewood, charcoal or waste as their main fuel source for cooking. Conversely, those who are connected to the gas and public water supply are, respectively, 1.34 and 1.91 percentage points more likely to have a good quality of life.

Missing at least one of the three daily meals recommended for a healthy diet (breakfast, lunch and dinner) also affects quality of life. The estimated coefficient in this case suggests that missing meals, presumably owing to lack of income, increases the probability of having only a fair quality of life by 14.85 percentage points. Given the magnitude of the coefficient and its high statistical significance $(1 \%)$, this result reveals an urgent need to analyse this problem in depth, and to develop programmes aimed at guaranteeing nutrition among older persons, since this is clearly a decisive factor in determining their well-being.

In view of this finding, a brief analysis of the Colombia Mayor programme was made from the standpoint of effect rather than cause, since, in the absence of an impact assessment study, it would be inappropriate to affirm or deny that the programme exerts a causal effect on the living conditions of older people. However, the analysis proposed in this research makes it possible to identify effects; and an analysis of the estimated coefficient and its statistical significance suggests that the living conditions of older people who receive these conditional transfers from the State do not affect their well-being, since the coefficient is negative in the "Very good" and "Good" categories. This may be because the programme targets individuals who have incomes of up to half the minimum wage, live alone, or are living in the street, or belong to levels 1 or 2 of the Potential Social Programme Beneficiary Identification System (SISBEN), among other conditions that clearly indicate low levels of quality of life and are unlikely to improve with the programme's subsidies.

Two variables were included in the model to analyse emotional stability and ascertain the effects of living with others in a household: the first variable, namely whether the home is owned and fully paid for, proves to be positively associated and raises the probability of having a good quality of life by 2.79 percentage points. The second variable, whether the person lives alone or is accompanied, showed that living alone reduced the likelihood of having a good or very good quality of life. These results suggest that companionship in old age is associated with greater well-being; and they are in line with the approach developed by Marín and others (2009) and Aldana and Pedraza (2012), for whom the feeling of loneliness is an important factor in depression among older people, which affects their quality of life. At the same time, policies aimed at improving conditions for acquiring a home will be justified by the future impact they will have on the population.

The last factor to be considered is the effect of marital status and level of schooling. Being married is associated with a better chance of having a quality of life rated good or very good, since any other marital status returns a negative coefficient. For example, it was found that being single or widowed is associated with a reduction in the likelihood of having a good quality of life by 4.12 and 2.14 percentage points, respectively. In the case of schooling, the econometric results indicate that quality of life improves with the level of human capital: the estimated coefficients show that the probability of enjoying a good quality of life increases between 2.42 percentage points for technical or technological education and by 2.68 points for university education.

This highlights the importance of education or training, not only for employment in early stages of the life cycle, but also for the quality of life later on. In descriptive terms, figure 3 shows that $58.7 \%$ of the older population have a basic primary or preschool level of education, while only $14.5 \%$ have a 
university training, which is positively associated with the likelihood of having a quality of life rated good or very good. It is therefore important to improve human capital continuously throughout the life cycle, to maintain adequate living conditions in old age.

Figure 3

Colombia: education level of older persons, 2018

(Percentages)

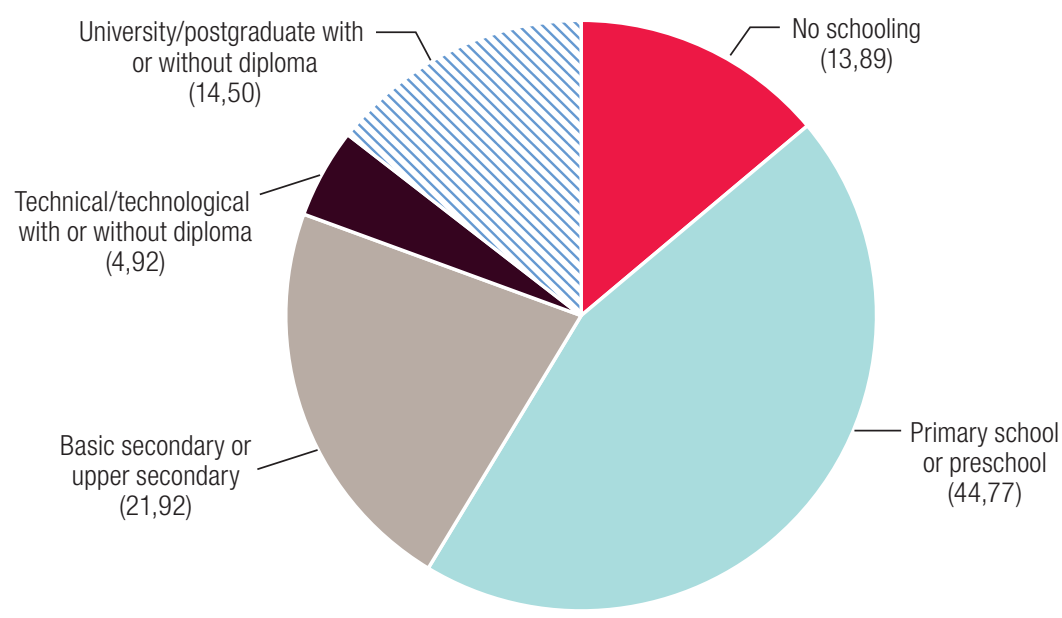

Source: Prepared by the authors, on the basis of data from the Quality of Life National Survey (ENCV) 2018.

One of the variables analysed in the third component is whether or not the person receives a pension and the impact of this on their quality of life. As noted in the literature review, this condition implies a loss of social roles which impairs quality of life. However, the estimated coefficient is not significant, so the present research considers that the data are not entirely conclusive for establishing the effect of receiving a pension on the well-being of older persons. As regards the social security system, being affiliated to the subsidized system reduces the likelihood of having a good quality of life, compared to older people who belong to the contributory system; while those in the special regime are more likely to enjoy a good quality of life than those in the subsidized system. Without being conclusive, the national literature reports serious problems in the subsidized health system ever since its creation: although the coverage of affiliates has increased, service providers have been unable to gain the financial capacity needed to offer a subsidized social security system of high quality (Gañán, 2010), which results in care problems that can clearly affect how users perceive their quality of life.

The perceptions component yields four major results, all of them with high statistical significance. A sense of security is associated with a better quality of life: the results show that this increases the probability of having a good quality of life by 11.59 percentage points relative to persons who feel insecure, which underlines the importance of addressing this external factor. In contrast, a perception of being in poverty is negatively related, since the probability of having a quality of life rated good or very good is reduced by 11.33 and 4.24 percentage points, respectively, among older people who consider themselves poor. Thus, the direct effect of the heterogeneous distribution of income on the standard of living in society is again an issue for discussion. Although this is not one of the key objectives of this research, by examining the determinants of poverty more closely, complementary empirical data are obtained for quality-of-life studies with a population-segmentation focus. 
The quality of the health service and individual health status are the last two indicators in the perceptions component. The results suggest that good health and a positive opinion of the quality of the health service increase the likelihood of having a very good quality of life by 23.86 and 2.28 percentage points, respectively. This result is consistent with the finding reported in the literature review; and health is one of the main factors when determining quality of life. Nonetheless, the coefficients of the other categories are also statistically significant: the reference category is to perceive a very bad health status and quality of service; so, any other perception raises the probabilities.

In order to explore whether there are regional characteristics that directly affect the quality of life and the development of opportunities for individuals to improve their socioeconomic level (such as schooling, among others), a dummy variable for geographical regions was added to the model. This makes it possible to assess whether the region in which the elderly person lives has any effect on his/her quality of life, and to investigate the existence of particular conditions by geographical characteristics. When using the Capital District of Bogotá as a reference category, the results showed that living outside this city-region is associated with a negative sign in some cases, which supports the hypothesis of divergences in the quality of life between regions.

Older people living in the Central region and the Valle del Cauca department are more likely to have a good quality of life than those in Bogotá; whereas a negative coefficient indicates that the quality of life is lower in the Atlántico department and the Pacific region. Although this reveals discrepancies between regions, it is impossible to make an argument to justify this, since objective data would be needed and conditions such as investments in the health system and care programmes for the elderly would have to be introduced in the specification. Nonetheless, the result confirms that disparities do exist. Figure 4 shows the relationship between quality of life and regions: the Pacific region has the highest proportion (45.72\%) of older people with a fair and poor quality of life, which shows that the model is capturing profound social dynamics which warrant in-depth exploration in future research on the subject.

Figure 4

Colombia: quality of life by region or department

(Percentages)

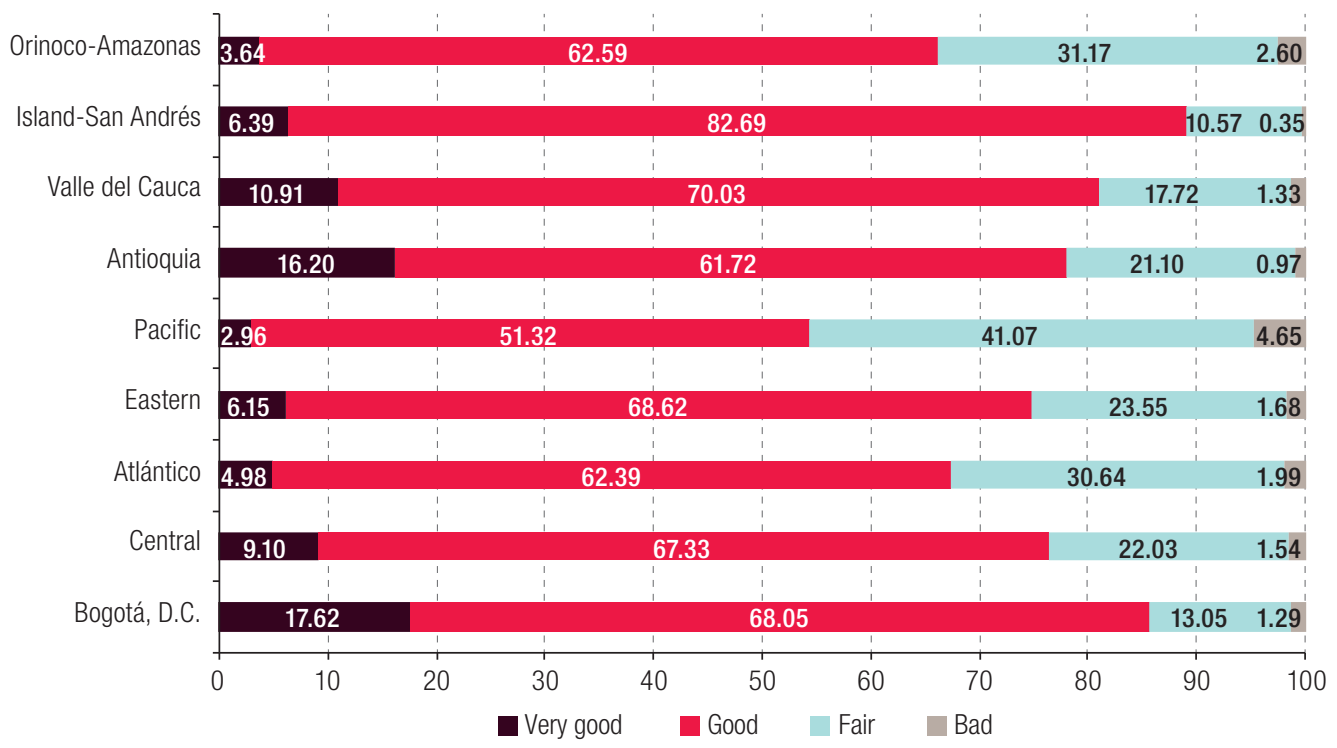

Source: Prepared by the authors, on the basis of data from the Quality of Life National Survey (ENCV) 2018. 


\section{Conclusions, recommendations and limitations}

Colombia's demographics, like those of other economies in the world, are characterized by an increase in the population's life expectancy. This is changing the shape of the population pyramid, which justifies the need for studies that analyse the quality of life of different population groups -in this case, older people - both quantitatively and using other approaches.

The proposed econometric estimation satisfies the conditions needed to sustain the technical rigour of the study's findings: the relationship between the regressors and the dependent variable is broadly in line with the theoretical approaches posited in other research. The discrete-choice ordered logit-type multinomial was an appropriate model for testing the research hypothesis as formulated and to attain the proposed objectives.

The key result in the demographic component suggests that old age is experienced in different ways depending on the age and sex of the individual in question. The socioeconomic component shows that missing at least one of the three daily meals recommended for an adequate diet, possibly owing to a lack of income, increases the probability of having only a fair quality of life by 14.85 percentage points. Policies are therefore needed to guarantee the nutrition of older people in addition to assistance programmes that increase their income, since this factor has a profound impact on their well-being. Social policies also need to be targeted by age structure and ethnic group, since people belonging to minority ethnic groups are shown to have poorer quality of life; and, although it is impossible to say that they deserve priority, they should be given greater attention.

The theoretical approaches to human capital developed by Solow (1956), Schultz (1961) and Becker (1964) are particularly important for this study, since the results show that older people with university or higher education are less likely to have only a fair quality of life and more likely to enjoy a quality of life rated good. This process clearly starts at an early age, so policies to promote educational inclusion and quality should be strengthened, to ensure that a large proportion of the population attains high levels of education.

The results of the perceptions component show how a sense of security is important for the quality of life of older people, as well as its impact on the probability of having a good quality of life. As regards the perception of poverty, the measurement is subjective, since, despite not being defined quantitatively, it is formulated relative to the norms of the society in which the individual is immersed. Policies should endeavour to improve the allocation of resources and, consequently, also the living conditions of society.

In terms of the original research question, having considered certain factors that are theoretically associated with quality of life, the conclusion is that older people in Colombia in 2018 are more likely to have a quality of life rated good than very good, and more likely to have a quality of life rated fair than bad (a probability of $80.18 \%$, compared to $14.85 \%$ in the case of only a fair quality of life).

On the other hand, the data show that the conditions specific to each region produce differential results in terms of their populations' quality of life. The research showed that older people living in the Central region or the Valle del Cauca department were more likely to have a good quality of life than those living in Bogotá. Based on these data, older people who are most likely to have a good or very good quality of life can be profiled as follows: being a woman, belonging to the medium and high socioeconomic level; not missing any daily meals; living in their own home; having technical or higher education and being affiliated to the contributory social security regime; not feeling insecure or considering themselves poor; feeling in good health and living in the Valle del Cauca department or the Central region. 


\section{Bibliography}

Alba, J. and others (2017), "Calidad de vida en adultos mayores institucionalizados en hogares geriátricos de Bogotá D.C. y municipios de Cajicá y Tenjo en segundo periodo 2017”, undergraduate dissertation, Bogota, University of Applied and Environmental Sciences.

Aldana, R. and J. Pedraza (2012), "Análisis de la depresión en el adulto mayor en la Encuesta Nacional de Demografía y Salud 2010", undergraduate dissertation, Bogota, Del Rosario University.

Arango, V. and I. Ruiz (2006), Diagnóstico de los adultos mayores de Colombia, Bogota, Saldarriaga Concha Foundation.

Araníbar, P. (2001), "Acercamiento conceptual a la situación del adulto mayor en América Latina", serie Población y Desarrollo, No. 21 (LC/L.1656-P), Santiago, Economic Commission for Latin America and the Caribbean (ECLAC).

Ávila-Funes, J., M. Garant and S. Aguilar-Navarro (2006), "Relación entre los factores que determinan los síntomas depresivos y los hábitos alimentarios en adultos mayores de México", Revista Panamericana de Salud Pública, vol. 19, No. 5, Washington, D.C., Pan American Health Organization (PAHO).

Bazo, M. (ed.) (1999), Envejecimiento y sociedad: una perspectiva internacional, Madrid, Editorial Médica Panamericana.

Becker, G. (1964), Human Capital: A Theoretical and Empirical Analysis, with Special Reference to Education, New York, Columbia University Press.

Bravo, J. (2000), "Envejecimiento de la población y sistemas de pensiones en América Latina", CEPAL Review, No. 72 (LC/G.2120-P), Santiago, Economic Commission for Latin America and the Caribbean (ECLAC).

Chackiel, J. (2000), "El envejecimiento de la población latinoamericana: ¿hacia una relación de dependencia favorable?", serie Population and Development, No. 4 (LC/L.1411-P), Santiago, Economic Commission for Latin America and the Caribbean (ECLAC).

Cuervas, M. (2004), "Tercera edad: los factores que dan calidad de vida", El Mercurio, Santiago, 4 October.

DANE (National Administrative Department of Statistics) (2017), "Estimación y proyección de población nacional, departamental y municipal por sexo, grupos quinquenales de edad y edades simples de $0 \mathrm{a}$ 26 años 1985-2020" [online] https://www.dane.gov.co/index.php/estadisticas-por-tema/demografia-ypoblacion/proyecciones-de-poblacion. (2016), "Encuesta Nacional de Calidad de Vida 2016", Bogota.

ECLAC (Economic Commission for Latin America and the Caribbean) (2004), Estrategia regional de implementación para América Latina y el Caribe del Plan de Acción Internacional de Madrid sobre el Envejecimiento, Santiago.

Ehlke, K. (1998), "La población adulta mayor", Enfermería gerontológica: cuidados integrales del adulto mayor, M. Burke and M. Walsh, Madrid, Harcourt Brace.

Escarbajal, A. and S. Martínez (2012), "Jubilación, educación y calidad de vida", Pedagogía Social. Revista Interuniversitaria, No. 20, Sevilla, Ibero-American Society of Social Pedagogy.

Estrada, A. and others (2011), "Calidad de vida de los adultos mayores de Medellín", Biomédica, vol. 31, No. 4, Bogota, National Institute of Health.

Fernández-Ballesteros, R. (1997), "Calidad de vida en la vejez: condiciones diferenciales", The UB Journal of Psychology, No. 73, Amsterdam, Elsevier.

Gañán, J. (2010), "Los muertos de Ley 100. Prevalencia de la libertad económica sobre el derecho fundamental a la salud: una razón de su ineficacia. Caso del Plan Obligatorio de Salud del Régimen Contributivo (POSC)", PhD dissertation, Externado University of Colombia.

Giraldo, G. and G. Arango (2012), "Caracterización de la jubilación y sus efectos en la calidad de vida de los docentes jubilados y en proceso de jubilación en el ambiente universitario", Eleuthera, vol. 6, Manizales, Caldas University.

Kaushal, N. (2014), "How public pension affects elderly labour supply and well-being: evidence from India", World Development, vol. 56, Amsterdam, Elsevier.

Lloyd-Sherlock, P. and others (2012), "Pensions, poverty and well-being in later life: comparative research from South Africa and Brazil", Journal of Aging Studies, vol. 26, No. 3, Amsterdam, Elsevier.

Mansfield, E. and B. Helms (1982), "Detecting multicollinearity", The American Statistician, vol. 36, No. 3a, Abingdon, Taylor \& Francis. 
Marín, G. and others (2009), "Evaluación del proyecto estatal de intervención para la mejora de la calidad de vida y la reducción de complicaciones asociadas al envejecimiento: 'Agrega salud a tus años'”, vol. 23, No. 4, Amsterdam, Elsevier.

Melguizo, E., A. Acosta and B. Castellano (2012), "Factores asociados a la calidad de vida de adultos mayores: Cartagena (Colombia)", Salud Uninorte, vol. 28, No. 2, Barranquilla, University of the North.

Pons, S. and others (2018), "Apreciación de la calidad de vida en el adulto mayor", Multimed, vol. 22, No. 1, Havana, Medical Sciences University of Granma.

Pugliese, L. (2010), "Las transformaciones familiares vistas a través de algunos indicadores de adultos mayores", Comentarios de Seguridad Social, No. 26, Montevideo, Social Security Bank.

Ramírez-Vélez, R. and others (2008), "Calidad de vida y condiciones de salud en adultos mayores no institucionalizados en Cali, Colombia", Journal of Public Health, vol. 10, No. 4, Bogota, National University of Colombia.

Rivera-Ledesma, A. and M. Montero (2005), "Espiritualidad y salud mental en adultos mayores mexicanos", Salud mental, vol. 28, No. 6, Mexico City, National Institute of Psychiatry Ramón de la Fuente Muñiz.

Rubio, D. and others (2015), "Calidad de vida en el adulto mayor", Varona, No. 61, Havana, Pedagogical University Enrique José Varona.

Schatz, E. and others (2012), "The impact of pensions on health and well-being in rural South Africa: does gender matter?", Social Science \& Medicine, vol. 75, No. 10, Amsterdam, Elsevier.

Schultz, T. (1961), "Investment in human capital", The American Economic Review, vol. 51, No. 1, Nashville, Tennessee, American Economic Association.

Solow, R. (1956), "A contribution to the theory of economic growth", The Quarterly Journal of Economics, vol. 70, No. 1, Oxford, Oxford University Press.

Varela, L. and E. Gallego (2015), "Percepción de la calidad de vida en un grupo de adultos mayores de Envigado (Colombia)", Salud \& Sociedad, vol. 2, No. 1, Tunja, Pedagogical and Technological University of Colombia.

Vega, E. (2009), "Prevención de caídas en el adulto mayor (revisión bibliográfica)", Revista Médica de Costa Rica y Centroamérica, vol. 67, No. 590, San José, Association of Public Health Physicians of Costa Rica. 


\section{Annex A1}

Table A1.1

Colombia: explanatory variables for the study of the quality of life of older people, 2018

\begin{tabular}{ll}
\hline Variables & Coding \\
\hline Quality of life & $0=$ Bad $1=$ Regular $2=$ Good $3=$ Very good \\
\hline Sex & $0=$ Woman $1=$ Man \\
\hline Marital status & $0=$ Married $1=$ Free Union $2=$ Widowed $3=$ Separated $4=$ Single \\
\hline Age & $0=$ Between 60 and 74 years old $1=$ Between 75 and 90 years old $2=$ Over 90 years old \\
\hline Ethnic minorities & $0=$ Not part of an ethnic minority $1=$ Part of an ethnic minority (Indigenous, Roma, \\
& Afro-Colombians, Raizal and Palenquero) \\
\hline Socioeconomic level & $1=$ Low $2=$ Medium $3=$ High \\
\hline Level of schooling & $0=$ None or basic $1=$ Baccalaureate $2=$ Technician or technologist $3=$ University \\
& $4=$ Specialization $5=$ Master or magister $6=$ Doctorate \\
\hline Lives alone & $0=$ No $1=$ Yes \\
\hline Log. Income & Natural logarithm of household income \\
\hline Own home & $0=$ Not own home $1=$ Own home \\
\hline Self-identification as poor & $0=$ Not Self-identifies as poor $1=$ Self-identifies as poor \\
\hline Major Colombia programme & $0=$ Not affiliated to the programme $1=$ Affiliated to the programme \\
\hline Social security regime & $0=$ Contributory regime $1=$ Special regime $2=$ Subsidized regime \\
\hline Firewood, charcoal or waste material used & $0=$ No $1=$ Yes \\
as a fuel for cooking & \\
\hline Connected to natural gas grid & $0=$ No gas available $1=$ Gas available \\
\hline Food prepared using water from public grid & $0=$ No $1=$ Yes \\
\hline Secure in the place of residence & $0=$ Doesn't feel secure $1=$ Feels secure \\
\hline One of the three meals missed for lack of money & $0=$ Yes eats all meals $1=$ No does not eat all meals \\
\hline Region or department & $0=$ Bogotá $1=$ Central $2=$ Atlántico $3=$ Eastern $4=$ Pacific $5=$ Antioquia $6=$ Valle del Cauca \\
\hline Quality of health service & $7=$ Island-San Andrés $8=$ Orinoco-Amazonas \\
\hline Health status & $0=$ Very bad $1=$ Bad $2=$ Good $3=$ Very good \\
\hline Receipt of a pension & $0=$ Very bad $1=$ Bad $2=$ Good $3=$ Very good \\
\hline Source: Prepar & $0=$ Does not receive a pension $1=$ Does receive a pension \\
\hline
\end{tabular}

Source: Prepared by the authors, on the basis of data from the Quality of Life National Survey (ENCV) 2018.

Table A1.2

Colombia: main statistics of the study of the quality of life of older people, 2018

\begin{tabular}{lccccc}
\hline Variable & Observations & Mean & Deviation & Minimum & Maximum \\
\hline Perception of quality of life & 20720 & 2.148 & 0.597 & 1.000 & 4.000 \\
\hline Sex [Male] & 20720 & 0.571 & 0.495 & 0.000 & 1.000 \\
\hline Ethnic minorities & 20720 & 0.098 & 0.297 & 0.000 & 1.000 \\
\hline Age & 20720 & 0.282 & 0.477 & 0.000 & 2.000 \\
\hline Socioeconomic level & 20720 & 0.461 & 0.632 & 0.000 & 2.000 \\
\hline Does not eat all of the three meals for lack of money & 20720 & 0.043 & 0.204 & 0.000 & 1.000 \\
\hline Prepares food with water from public grid & 20720 & 0.796 & 0.403 & 0.000 & 1.000 \\
\hline Connected to natural gas grid & 20720 & 0.695 & 0.460 & 0.000 & 1.000 \\
\hline Uses firewood, charcoal or waste material to cook food & 20720 & 0.104 & 0.306 & 0.000 & 1.000 \\
\hline Lives alone & 20720 & 0.236 & 0.424 & 0.000 & 1.000 \\
\hline Log Income & 20720 & 14.197 & 1.188 & 8.034 & 18.590 \\
\hline Level of schooling & 20720 & 1.637 & 1.212 & 0.000 & 4.000 \\
\hline Marital status & 20720 & 1.436 & 1.203 & 0.000 & 3.000 \\
\hline Has own home & 20720 & 0.725 & 0.446 & 0.000 & 1.000 \\
\hline Colombia Major programme & 20720 & 0.216 & 0.412 & 0.000 & 1.000 \\
\hline Receives a pension & 20720 & 0.694 & 0.461 & 0.000 & 1.000 \\
\hline Social security scheme & 20720 & 0.924 & 0.973 & 0.000 & 2.000 \\
\hline Feels secure in place of residence & 20720 & 0.812 & 0.391 & 0.000 & 1.000 \\
\hline Self-identifies as poor & 20720 & 0.365 & 0.481 & 0.000 & 1.000 \\
\hline Quality of health service & 20720 & 1.844 & 0.629 & 0.000 & 3.000 \\
\hline Health status & 20720 & 1.625 & 0.636 & 0.000 & 3.000 \\
\hline Region & 20720 & 2.797 & 2.081 & 0.000 & 8.000 \\
\hline Source: Prepared by the & & &
\end{tabular}

Source: Prepared by the authors, on the basis of data from the Quality of Life National Survey (ENCV) 2018. 
Table A1.3

Colombia: information criteria for the choice of model in the study of the quality of life of older people, 2018

\begin{tabular}{lcc}
\hline Statistic & Ordered Logit & Ordered Probit \\
\hline LL & -14400 & -14400 \\
\hline AIC & 28923.324 & 28924.296 \\
\hline BIC & 29264.695 & 29265.667 \\
\hline Pseudo $\mathrm{R}^{2}$ & 0.225 & 0.225 \\
\hline
\end{tabular}

Source: Prepared by the authors, on the basis of data from the Quality of Life National Survey (ENCV) 2018.

Note: LL - Log likelihood; AIC - Akaike information criterion; and BIC -Bayesian information criterion.

Table A1.4

Colombia: variance inflation factor (VIF) of the variables in the study of the quality of life of the elderly, 2018

\begin{tabular}{lcc}
\hline Variable & VIF & $1 /$ VIF \\
\hline Log. income & 2.24 & 0.4471 \\
\hline Socioeconomic level & 2.19 & 0.4560 \\
\hline Marital status & 1.91 & 0.5225 \\
\hline Prepares food using water from public grid & 1.91 & 0.5226 \\
\hline Connected to natural gas grid & 1.86 & 0.5376 \\
\hline Level of schooling & 1.86 & 0.5383 \\
\hline Socioeconomic level & 1.78 & 0.5623 \\
\hline Uses firewood, charcoal or waste material as a cooking fuel & 1.62 & 0.6162 \\
\hline Sex [Male] & 1.52 & 0.6563 \\
\hline Colombia Major programme & 1.51 & 0.6637 \\
\hline Lives alone & 1.46 & 0.6868 \\
\hline Has a pension & 1.44 & 0.6966 \\
\hline Self-identifies as poor & 1.37 & 0.7277 \\
\hline Health status & 1.19 & 0.8434 \\
\hline Age & 1.14 & 0.8801 \\
\hline Own home & 1.1 & 0.9098 \\
\hline Region & 1.09 & 0.9173 \\
\hline Social security regime & 1.07 & 0.9363 \\
\hline Quality of health service & 1.07 & 0.9385 \\
\hline Misses one of the three daily meals for lack of money & 1.06 & 0.9438 \\
\hline Ethnic minorities & 1.05 & 0.9485 \\
\hline Average VIF & 1.41 & \\
\hline
\end{tabular}

Source: Prepared by the authors, on the basis of data from the Quality of Life National Survey (ENCV) 2018. 